\title{
Woody Biomass and Bioenergy Potentials in Southeast Asia between 1990 and 2020
}

\section{Citation}

Sasaki, Nophea, Wolfgang Knorr, David R. Foster, Hiroko Etoh, Hiroshi Ninomiya, Sengtha Chay, Sophanarith Kim, and Sengxi Sun. 2009. Applied Energy 86(Supp 1): S140-S150.

\section{Published Version}

doi:10.1016/j.apenergy.2009.04.015

\section{Permanent link}

http://nrs.harvard.edu/urn-3:HUL.InstRepos:11077568

\section{Terms of Use}

This article was downloaded from Harvard University's DASH repository, and is made available under the terms and conditions applicable to Other Posted Material, as set forth at http:// nrs.harvard.edu/urn-3:HUL.InstRepos:dash.current.terms-of-use\#LAA

\section{Share Your Story}

The Harvard community has made this article openly available.

Please share how this access benefits you. Submit a story.

\section{Accessibility}


2

3 Nophea Sasaki ${ }^{1,2}$, Wolfgang Knorr ${ }^{3}$, David R. Foster ${ }^{1}$, Hiroko Etoh ${ }^{2}$, Hiroshi Ninomiya ${ }^{2}$, 4 Sengtha Chay ${ }^{2}$, Sophanarith Kim ${ }^{4}$, Sengxi Sun ${ }^{2}$,

$7 \quad{ }^{1}$ Harvard Forest, Harvard University

8324 North Main Street, Petersham, MA 01366, USA

$9 \quad{ }^{2}$ Graduate School of Applied Informatics, University of Hyogo

10 Kobe, Japan

$11{ }^{3}$ QUEST, Department of Earth Sciences, University of Bristol

12 Bristol, UK

$13{ }^{4}$ KIMSAS Services, Phnom Penh, Cambodia

14

15

16

17

18

19

20

21

22 


\section{Abstract}

24 Forests in Southeast Asia are important sources of timber and other forest products, of 25 local energy for cooking and heading, and potentially as sources of bioenergy. Many of 26 these forests have experienced deforestation and forest degradation over the last few 27 decades. The potential flow of woody biomass for bioenergy from forests is uncertain and 28 needs to be assessed before policy intervention can be successfully implemented in the 29 context of international negotiations on climate change. Using current data, we developed a 30 forest land use model and projected changes in area of natural forests and forest plantations from 1990 to 2020 . We also developed biomass change and harvest models to estimate woody biomass availability in the forests under the current management regime. Due to deforestation and logging (including illegal logging), projected annual woody biomass production in natural forests declined from 815.9 million tons (16.3 EJ) in 1990 to 359.3 million tons $(7.2 \mathrm{EJ})$ in 2020 . Woody biomass production in forest plantations was estimated at 16.2 million tons $\mathrm{yr}^{-1}(0.3 \mathrm{EJ})$, but was strongly affected by cutting rotation length. Average annual woody biomass production in all forests in Southeast Asia between 1990 and 2020 was estimated at 563.4 million tons (11.3 EJ) $\mathrm{yr}^{-1}$ declining about $1.5 \% \mathrm{yr}^{-1}$.

39 Without incentives to reduce deforestation and forest degradation, and to promote forest rehabilitation and plantations, woody biomass as well as wood production and carbon stocks will continue to decline, putting sustainable development in the region at risk as the majority of the population depend mostly on forest ecosystem services for daily survival.

44 Keywords: Woody biomass; wood bioenergy; deforestation; forest degradation; land use change; selective logging; Southeast Asia 


\section{1. Introduction}

50 International concerns about global warming caused by excessive emissions of greenhouse 51 gases led to the adoption of the Kyoto Protocol to the United Nations Convention on Climate Change (UNFCCC) in 1997. The protocol commits industrialized countries, known as Annex I countries, to reduce greenhouse gas emissions during the first commitment period between 2008 and 2012. As the first year of the first commitment period ended, discussions for the post-Kyoto climate change agreements were carried out in December 2008 in Poznan, Poland. Several industrialized countries have pledged to reduce carbon emissions by up to $80 \%$ [1]. In addition to increasing energy efficiency and increased reliance on renewable energy sources such as wind and solar power, reducing emissions from deforestation and forest degradation (REDD) is likely to be a important

60 mitigation option in the post-Kyoto agreements, because deforestation and forest 61 degradation are responsible for the release of about 1.5 to $2.2{\mathrm{Gt} \mathrm{C} \mathrm{yr}^{-1}}^{[}[2,3]$ or about up to $62 \quad 25 \%$ of annual global emissions. In addition to increasing carbon emissions, deforestation and forest degradation reduce availability of woody biomass, on which approximately $2.5-2.7$ billion people $[4,5]$ depend for daily cooking fuel. Given the widespread dependency on wood for energy and

67 the importance of forests to mitigate climate change, there is a strong need to assess the

68 future availability while developing a path toward the sustainable use and management of

69 forests. Canadell and Raupach [6] proposed four strategies for managing forests for climate 
change mitigation. One of the strategies is to expand the use of woody biomass to replace the use of fossil fuels. Smeets et al. [7] provided an assessment of wood bioenergy potentials on a global scale, concluding that there is high potential of woody biomass from forests. Kinoshita et al. [8] evaluated the utilization of thinned wood as bioenergy in Japan and concluded that bioenergy is increasingly important in substituting for the use of oil. Utilization of woody biomass has a potential role in global warming mitigation because of its low emissions of greenhouse gases compared to the utilization of oil or coal for power generation $[7,8,9]$. To avoid power shortages such as occurred in 2001 in Brazil, the Brazilian government has launched incentive programs to encourage the utilization of biomass (including woody biomass) as bioenergy [10]. All these studies show the importance of woody biomass in climate change mitigation and sustainable development.

Although the Food and Agricultural Organization of the United Nations' Regional Wood Energy Development Program (referred to as FAO-RWEDP hereafter, [5]) provided an estimate of woodfuels in South and Southeast Asia, their estimate did not incorporate the illegal logging activities and significant logging damages that occur commonly in the region $[11,12,13]$. Their estimate also did not consider local uses of wood, an important consideration given the fact that the availability of woody biomass is directly linked to daily survival in this region. About $30-90 \%$ of the population in individual countries in Southeast Asia depends entirely on woody biomass for daily cooking and heating [14]. Furthermore, as deforestation and forest degradation continue, the future availability of wood for this region is at risk. Between 1990 and 2005, forest area in Southeast Asia 
93 [15]. In addition, forest degradation due to logging (including illegal logging) and related 94 damages causes the gradual loss of forest biomass and carbon stocks [16]. As the 95 population and the demand for woody biomass continue to rise, the current and future 96 availability of woody biomass need to be assessed so that appropriate policies can be 97 introduced.

99 The aim of this study is to provide an assessment of the availability of woody biomass and 100 bioenergy in eleven countries in Southeast Asia under current forest management regime, 101 which includes illegal logging and logging damages. The paper is structured as follows: 1) 102 forest land use change models are developed to estimate the rate of deforestation and reforestation through forest plantations; 2) woody biomass and harvesting models are

104 developed to estimate the biomass changes under current management regimes, and 105 potential woody biomass for bioenergy generation is estimated.

\section{2. Materials and Methods}

108 2.1. Forests in Southeast Asia

109 Southeast Asian countries in our study include Brunei, Burma, Cambodia, East Timor, 110 Indonesia, Laos, Malaysia, Philippines, Singapore, Thailand, and Vietnam. This region has 111 experienced fast economic development and the gradual loss of forest resources. Changes 112 in areas of natural forests and forest plantations between 1990 and 2005 are given in Table

113 1. According to FAO [15], natural forests consist of production, multiple-purpose, and 
114 unspecified forests, protected forest, conservation forest, and forest for social services. The

115 first three categories are grouped as production forest $(P d F)$, where commercial logging

116 and land development can take place, while the latter three categories are grouped as

117 protected forest $(\operatorname{Pr} F)$, where traditional firewood collection and small-scale logging for

118 housing by local forest communities can take place. There are two types of forest

119 plantations (FP) in the tropics, namely fast growing species plantation (FPf), which

120 account for $47 \%$ of the total plantations and slow growing species plantation (FPs), which

121 account for the rest [17]. For our study the proportion of fast and slow growing plantation

122 remains unchanged during the modeling period between 1990 and 2020.

124 2.2. Land use models

125 Over the last 15 years, although area of natural forests in Southeast Asia continued to 126 decrease, area of forest plantations slowly increased as shown in Table 1. It could be 127 argued that part of the deforested lands was replaced by forest plantations. Therefore, for 128 our study, it is assumed that deforested lands are partially replaced by forest plantations

129 (see Fig.1 for illustration). With this assumption, the change in area of natural forests and

130 forest plantations can be estimated using models developed by Kim Phat et al. [16]:

$$
\frac{\mathrm{dPdF}(\mathrm{t})}{\mathrm{dt}}=-\left(\mathrm{k}_{\mathrm{a}}+\mathrm{k}_{\mathrm{b}}\right) \cdot \operatorname{PdF}(\mathrm{t})
$$

$133 \quad \frac{\mathrm{dPrF}(\mathrm{t})}{\mathrm{dt}}=0$

$134 \quad \frac{\mathrm{dFP}(\mathrm{t})}{\mathrm{dt}}=\mathrm{k}_{\mathrm{a}} \cdot \operatorname{PdF}(\mathrm{t})$ 
135 where $\operatorname{PdF}(t)$ is production forest at time $t, \operatorname{Pr} F(t)$ is protected forest, $F P(t)$ is forest

136 plantation, $-\left(k_{a}+k_{a}\right)$ is the change of $P d F(t)$, and $k_{a}$ is the change of $F P(t)$

137

138 Data in Table 2 are used to derive $-\left(k_{a}+k_{b}\right), k_{a}$, and the initial values ( $\mathrm{t}=0$ in 1990) for areas 139 of $P d F$ and FP using linear regression methods. According to FAO [15], the area of 140 protected forests in the tropics increased by approximately $0.07 \%$ from 1990 to 2005 . 141 During the modeling period of this study, $\operatorname{Pr} F$ is considered to remain unchanged.

142

2.3. Woody biomass models

147 Standing biomass refers to all above-ground biomass in tons of dry matter, woody biomass

148 refers to biomass available for bioenergy generation, and bioenergy refers to energy

149 content in woody biomass. Leaves and root biomass are not included.

150

151 2.3.1. Natural forests:

152 A conceptual diagram illustrating the allocation of biomass is given in Fig. 2.

153 
156 To estimate the standing biomass change in Southeast Asia, the following equations

157 modified from Kim Phat et al. [16] are used:

158

159

$$
\frac{\mathrm{dSB}_{\mathrm{i}}(\mathrm{t})}{\mathrm{dt}}=\mathrm{MAI}_{\mathrm{i}}-\mathrm{H}_{\mathrm{i}}(\mathrm{t})-\mathrm{ddB}_{\mathrm{i}}(\mathrm{t})
$$

160

$$
H_{i}(t)=\frac{f_{w} \cdot f_{T}}{1-r} \cdot \frac{S B_{i}(t)}{C C}
$$

$$
\operatorname{ddB}_{\mathrm{i}}(\mathrm{t})=\mathrm{H}_{\mathrm{i}}(\mathrm{t})
$$

$$
\mathrm{WAS}_{\mathrm{i}}(\mathrm{t})=\mathrm{s} \cdot \mathrm{H}_{\mathrm{i}}(\mathrm{t})
$$

164 where $S B_{i}(t)$ is standing biomass in $i$ forest $(P d F, \operatorname{PrF})$ (ton ha $\left.{ }^{-1}\right), M A I_{i}$ is mean annual biomass increment, $H_{i}(t)$ is harvested biomass, $\mathrm{ddB}_{\mathrm{i}}(\mathrm{t})$ is dead biomass caused by logging, $W A S_{i}(\mathrm{t})$ is biomass waste due to trimming, felling, skidding and/or transporting, $f_{W}$ is the fraction of harvested stand biomass, $f_{T}$ is the fraction of mature-tree stand biomass, $C C$ is the cutting cycle, $r$ is the illegal logging rate, $s$ is the rate of biomass waste. It is unlikely that illegal loggers will harvest immature trees because of no market demand for such trees,

170 and therefore $\mathrm{r} \leq 1-\mathrm{f}_{\mathrm{w}}$. In our study the values for $M A I, W A S, f_{W}, f_{T}, C C$, and $r$ (Table 3)

171 are based on various country reports [16]. Under conventional logging in East Kalimantan,

172 every one cubic meter of harvested wood resulted in the dying of $0.9-1.2 \mathrm{~m}^{3}$ of life 173 biomass [18]. In the same region, Sist et al. [19] estimated that logging 10 trees caused 174 damage to other 309 trees all with a diameter at breast height over $10 \mathrm{~cm}$, of which 206 175 trees were killed immediately. Therefore, for this study, $d_{d B_{i}}(t)$ is assumed to be the same 
as $\mathrm{H}_{\mathrm{i}}(\mathrm{t})$ for every time step. An energy content of $20 \mathrm{GJ}$ ton $^{-1}$ of dry woody biomass [20] is used for energy estimates for biomass from natural forests and forest plantations.

Total woody biomass available for bioenergy (BIE) in natural forests (NF) is estimated as:

where $i u W A S_{i}(t)$ is iuWPi is iuWASi is in-use wasted wood due to wood processing at the wood processing factories (see Fig. 2), $N F_{i}(t)$ is $\operatorname{PdF}(t)$ and $\operatorname{Pr} F(0)$

$$
\mathrm{BIE}(\mathrm{t})=\sum_{\mathrm{i}=1}^{2}\left[\mathrm{ddB}_{\mathrm{i}}(\mathrm{t})+\mathrm{WAS}_{\mathrm{i}}(\mathrm{t})+\mathrm{iuWAS}_{\mathrm{i}}(\mathrm{t})\right] \cdot \mathrm{NF}_{\mathrm{i}}(\mathrm{t})
$$

(1)

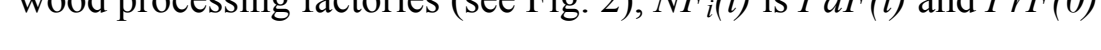

Total biomass available for furniture making (BIF) is estimated as:

$87 \quad B I F(t)=\sum_{i=1}^{2} i u W P_{i}(t) \cdot N F_{i}(t)$

where $i u W P_{i}$ is in-use wood product (see Fig. 2)

\subsubsection{Forest plantations:}

192 Unlike natural forests, mean annual increment is faster in forest plantations, where a clear-

193 cut system is applied. For this study, a logistic model is used to estimate biomass in forest

194 plantations:

195 


$$
\frac{\mathrm{dSB}_{\mathrm{j}}(\mathrm{t})}{\mathrm{dt}}=\alpha_{j} \cdot S B_{j}(t) \cdot\left(1-\frac{S B_{j}(t)}{S B_{M A X, j}}\right)
$$

198 where $S B_{j}(t)$ is standing biomass in $j$ plantations ( $j$ is fast-growing plantation, $F P f$ and

199 slow-growing plantation, $F P S$ ) (ton $\left.\mathrm{ha}^{-1}\right), \alpha_{j}$ is the growth rate of a forest plantation, $B_{M A X, j}$

200 is the maximum wood biomass that a plantation can reach. Based on Brown [26] in Table 2014 , average standing biomass increment is 7.7 and 5.9 ton $\mathrm{ha}^{-1} \mathrm{yr}^{-1}$ (see note under Table 4 202 for calculation) over 10-yr and 40-yr cutting rotation $(C R)$ (Table 4, Table 5) for $F P f$ and $F P s$, respectively (see note under Table 4 for calculation). In reality, $B_{M A X, j}$ is unknown because forest plantations are usually harvested before they reach maturity age. For this study, $B_{M A X, j}$ is assumed at 200 and 300 ton $\mathrm{ha}^{-1}$ for FPf and FPs. With these assumptions, $\alpha$ and $S B_{j}(0)$ for $F P f$ and $F P S$ are derived at 0.2765 and 0.1337 , and 7.7 and 5.9 ton $\mathrm{ha}^{-1} \mathrm{yr}^{-}$

$207^{1}$, respectively. All harvested stem biomass is assumed to be used for pulp production $208\left(P P L_{j}\right)$, and the rest in branches and top logs are summed to be woody biomass for 209 bioenergy generation $\left(d d B_{j}\right)$ (see Fig. 2). Biomass in leaves $(1.9 \%$ of the total above210 ground biomass [23]) is left behind in the field.

214 Total standing biomass in forest plantation $j, \operatorname{SBFP}_{j}(t)$ at time $t$, is

215

216

$$
\operatorname{SBFP}_{\mathrm{j}}\left(\mathrm{t}_{\mathrm{n}}\right)=F P A_{\mathrm{j}}\left(\mathrm{t}_{0}\right) \times S B_{\mathrm{j}}\left(\mathrm{t}_{\mathrm{n}}\right)+\mathrm{FPA}_{\mathrm{j}}\left(\mathrm{t}_{1}\right) \times S B_{\mathrm{j}}\left(\mathrm{t}_{\mathrm{n}-1}\right)+\ldots+\operatorname{FPA}_{\mathrm{j}}\left(\mathrm{t}_{\mathrm{n}}\right) \times S B_{\mathrm{j}}\left(\mathrm{t}_{0}\right)
$$


218 where $F P A_{j}(t)$ is the actual planted area at time $t$ (million ha).

219

220 Total standing biomass in all plantations $\left(S B F P_{\text {TOTAL }}\right)$ is therefore:

221

222

$$
\operatorname{SBFP}_{\text {TOTAL }}\left(\mathrm{t}_{\mathrm{n}}\right)=\sum_{\mathrm{j}=1}^{2} \operatorname{SBFP}_{\mathrm{j}}\left(\mathrm{t}_{\mathrm{n}}\right)
$$

223

224 Once each forest plantation reaches the $C R$ age $(t=C R)$, all biomass is harvested.

225 Plantations established in 1990 (start of the model) will be harvested in 1999 for FPf and in 2029 for FPs. Replanting is assumed to be carried out one year after harvesting.

227

Total biomass available for pulp production $(B I P)$ at time $t=\mathrm{n}$ in forest plantations is

229

230

$$
\operatorname{BIP}\left(t_{n}\right)=\sum_{j=1}^{2} \frac{\operatorname{SBFP}_{j}\left(t_{n}\right)}{\mathrm{BEF}_{j}}
$$

231

232 where $B E F_{j}$ is a biomass expansion factor (see note under Table 4)

233

234 And woody biomass available for bioenergy $(B I E)$ at time $t=\mathrm{n}$ is

235

$$
\operatorname{BIE}\left(t_{n}\right)=\sum_{j=1}^{2} \operatorname{SBFP}_{j}\left(t_{n}\right)-\operatorname{BIP}_{j}\left(t_{n}\right)
$$




\section{Results and Discussions}

\subsection{Changes in area of forests}

239 Over the modeling period, the area of natural forests declines from 245.9 million ha (231.1 240 for the $95 \%$ lower bound and 262.3 for the upper bound) in 1990 to 173.7 million ha $241(165.6-182.6)$ in 2020 , losing annually about $2.0 \%\left[-\left(\mathrm{k}_{\mathrm{a}}+\mathrm{k}_{\mathrm{b}}\right)=-0.0202\right]$. Mean annual 242 changes in area of natural forests and forest plantation are estimated at 2.8 million ha $\mathrm{yr}^{-1}$ 243 between 1990 and 2005, and 2.4 million ha $\mathrm{yr}^{-1}$ between 1990 and 2020 (Table 6). The 244 area of forest plantations slowly increases to 16.0 million ha (15.2-16.8) from 10.1 million 245 ha (9.8-10.2) in 1990, increasing about 0.2 million ha $\mathrm{yr}^{-1}$ (Fig. 3). Because only about $2460.09 \%\left(\mathrm{k}_{\mathrm{a}}=0.0009\right)$ of deforested forestland is converted to forest plantations, our results suggest that most of the deforested land is converted to other types of land uses.

248 Altogether, Southeast Asia loses about 2.2 million ha $\mathrm{yr}^{-1}(2.0-2.4)$ of forests over the modeling period (Table 6). A previous study by Kim Phat et al. [16] estimated deforestation in this region at 1.6 million ha $\mathrm{yr}^{-1}$ between 1980 and 2050. This variation may be due to the different modeling timeframe and the data used. Deforestation between 1990 and 2005 is estimated at 2.6 million ha $\mathrm{yr}^{-1}$ by our model, which matches very well with that estimated by FAO [15].

256 3.2. Standing biomass changes

257 Owing to deforestation and forest degradation, standing biomass in natural forests rapidly 258 declines from 45858.7 million tons (about 957.2 EJ) in 1990 to 26597.4 million tons 
259 (531.9 EJ) in 2020, losing about 708.7 million tons $\mathrm{yr}^{-1}(14.2 \mathrm{EJ})$ or about $1.5 \% \mathrm{yr}^{-1}$. 260 Standing biomass in forest plantations is strongly influenced by cutting rotation, increasing 261 to 1013.8 million tons (20.3 EJ) in 2020 from merely 67.8 million tons (1.3 EJ) in 1990 . 262 Altogether, Southeast Asian forests are projected to lose about 677.2 million tons $\mathrm{yr}^{-1}$ (13.5 263 EJ) between 1990 and 2020 (Table 7).

3.3. Annual woody biomass and bioenergy production

In terms of woody biomass, natural forests produce, an average of 547.2 \pm 24.6 million tons $\mathrm{yr}^{-1}$ ( \pm is standard error) (10.9 EJ) between 1990 and 2020, decreasing from $657.8 \pm 23.0$ million tons $\mathrm{yr}^{-1}$ (13.1 EJ) between 1990 and 2005 (Fig. 4, Table 8). Forest plantations produce another $16.2 \pm 7.5$ million tons $\mathrm{yr}^{-1}(0.3 \mathrm{EJ})$ between 1990 and 2020. Altogether, total annual production of woody biomass is 563.4 million tons (11.3 EJ) over the same period between 1990 and 2020. Total energy consumption in Southeast Asia was estimated at $6.4 \mathrm{EJ}$ in 1990 and $15.7 \mathrm{EJ}$ in 2006, increasing about $9.0 \% \mathrm{yr}^{-1}$ [30]. Energy from

274 woodfuels in Southeast Asia (excluding Singapore and Brunei) was estimated at 2.4 EJ in 1993 [14] or about $33.1 \%$ of the total energy consumption in that year [30]. Energy from

276 woodfuels in this region increased, on average about $2.5 \% \mathrm{yr}^{-1}$ between 1992 and 1995 277 [14]. Therefore, without effective policy to reducing deforestation and forest degradation, 278 energy shortage is likely to occur in Southeast Asia. 
281 Using carbon coefficients of $25 \mathrm{KgC} \mathrm{GJ}^{-1}$ for coal, $20 \mathrm{KgC} \mathrm{GJ}^{-1}$ for petroleum products, 282 and $15 \mathrm{KgC} \mathrm{GJ}^{-1}$ for natural gas [31], carbon emission reductions associated with using 283 woody biomass instead of fossil fuels for energy generation are estimated at $281.7 \mathrm{TgC}^{-}$ $284{ }^{1}$ for replacing coal, $225.3{\mathrm{TgC} \mathrm{yr}^{-1}}^{1}$ for replacing petroleum products, and $169.0 \mathrm{TgC}^{-1}$ 285 for replacing natural gas throughout the modeling period (Table 8).

3.4. Comparison with previous studies

289 Our models project $92.0 \pm 4.1$ (52.4 million tons) and $64.8 \pm 30.2$ million $\mathrm{m}^{3}$ (33.3 million tons), of wood for furniture making and pulpwood production over the modeling period (Table 8). Industrial roundwood in Cambodia, Indonesia, Laos, Malaysia, Myanmar, Philippines, Thailand, and Vietnam between 1991 and 2001 was reported at 77.2 \pm 5.6 million $\mathrm{m}^{3} \mathrm{yr}^{-1}$ [32]. With the addition of roundwood from illegal logging $(\mathrm{r}=0.53)$, the above figure would have been 164.2 million $\mathrm{m}^{3}[=77.2 /(1-0.53)]$, which is equivalent to about 82.2 million $\mathrm{m}^{3}(=164.2 * 0.5,0.5$ is wood processing efficiency) of end-use wood products, about 9.8 million $\mathrm{m}^{3}$ lower than our estimate. This difference may be due to the unreported wood production from illegal logging in some countries in the region.

299 Results from previous studies on wood bioenergy using different methods and assumptions

300 are also compared here. Surrounded by uncertainties as identified by Koopmans [5], FAO-

301 RWEDP estimated the potential wood bioenergy from forested land in Southeast Asia at 302 about $6.7 \mathrm{EJ}$ in 1994. If no illegal logging would take place, our model estimates wood 
bioenergy at 7.0 EJ in 1994 and $5.9 \mathrm{EJ} \mathrm{yr}^{-1}$ between 1990 and 2020 in the same region

304 (Table 9). Smeets \& Faaij [7] estimated the loss of wood bioenergy due to tropical 305 deforestation at $13.0 \mathrm{EJ} \mathrm{yr}^{-1}$ between 1998 and 2050. Our estimate of wood bioenergy loss

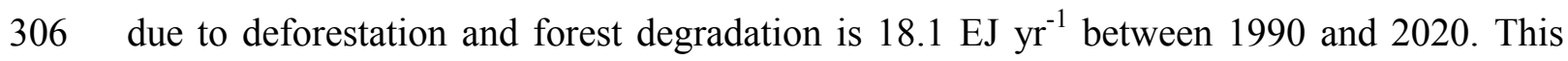
307 difference may result from different methods and assumptions (Table 9). Using a global 308 land-use and energy model (GLUE), Yamamoto et al. [33] estimated wood bioenergy in all 309 developing countries worldwide at 45.9-85.2 EJ in 2100. Because of the difference in 310 study methods, assumptions, and scales, the results of their study are expected to be higher 311 than our estimate for Southeast Asia only.

\section{Sensitivity Analysis}

316

317 Illegal logging is strongly affected by the political stability and governance in Southeast 318 Asia. If an illegal logging rate of $73 \%(r=0.73)$ as reported in Indonesia [37] is used in all 319 natural forests (NF), standing biomass in NF declines from 47858.7 million tons (957.2 EJ) 320 in 1990 to 20652.2 million tons (413.0 EJ) in 2020, a loss of about $1.9 \%$ annually. If illegal 321 logging is eliminated $(\mathrm{r}=0)$, standing biomass declines to 32393.3 million tons (647.9 EJ), 322 losing only about $1.1 \%$ as a result of deforestation (Fig. 5). In terms of woody biomass 323 production, our models project the mean annual production from all forests at $301.0(6.0$ 324 EJ), $563.8(11.3$ EJ), and 831.7 million tons $(16.6 \mathrm{EJ})$ for $\mathrm{r}=0, \mathrm{r}=0.53(\mathrm{r}=0.53$ was used in 
our study), and $\mathrm{r}=0.73$, respectively (Fig. 6). According to Fig. 6, illegal logging is likely natural forests in Vietnam. International policy may influence biomass production. For example, if ongoing discussions lead to the inclusion of the reduced emissions from

330 deforestation and degradation (REDD) in the post-Kyoto climate change agreement period 331 from 2013 to 2020, a large amount of biomass loss as well as carbon emissions could be 332 prevented. Therefore, woody biomass production will also change. Once slow growing 333 plantations become harvestable, woody biomass production is expected to increase as well.

335 Another uncertainty of our study relates to the potential increase of woody biomass 336 obtaining from forest rehabilitation as being increasingly implemented in Indonesia [38],

337 Philippines [39], and Vietnam ([40], but see Meyfroidt and Lambin [41]). Forest 338 rehabilitation could bring the deforested land or severely degraded forest back to its pre339 harvest level, and therefore would eventually increase woody biomass. Annual or biannual 340 re-assessment may reduce the future uncertainties regarding biomass projection.

\section{5. Policy Implications for Woody Biomass Production under REDD}

345 The current climate change agreement discussions include REDD in the post-Kyoto 346 agreements and give hope for tropical forest conservation. The Bali Action [42] and the 
347 sustained interest in REDD during the $14^{\text {th }}$ conference of the parties in Poznan in

348 December in 2008 [43] have led to increased attention to REDD [44, 6]. If REDD is finally

349 adopted, well-defined land use and logging planning that addresses the causes of 350 deforestation is required. The causes of deforestation in Southeast Asia could be classified 351 to be 1) the need for land for agricultural cultivation to feed increasing population [45], 2)

352 industrial plantation development [46], and 3) indiscriminate logging [12, 24, 47]. The

353 former is unavoidable because of the need for survival and requires well-assessed planning

354 and policies to encourage sustainable practices. The latter two may be due to policy

355 failures or the lack for incentives for long-term conservation of tropical forests. Economic, 356 social, and ecological assessments of different land use options that take into consideration 357 the financial incentives for protecting natural forests under REDD agreements are 358 necessary so that resource managers-be they government or companies- will have a clear 359 picture in terms of the financial returns and long-term social and ecological consequences 360 of their decisions.

362 In order to control indiscriminate logging and its associated forest degradation, incentives 363 are needed to promote reduced impact logging (RIL) which has been proven to reduce 364 damages $[12,24]$ to residual trees and soil, reduce wood waste (the latter is due to 365 untrained trimming, skidding, and transporting), and increase carbon sinks [47]. The 366 REDD agreements are likely to result in decreases in woody biomass, as overexploitation 367 and illegal logging would be gradually brought under control and the perpetual flow of 368 ecosystem services for sustainable development could be ensured. As forest rehabilitation 
369 projects have been increasingly implemented in Indonesia [38], Philippines [39], and

370 Vietnam [40, 41], incentives for further promoting the widespread implementation of such

371 projects in other countries in the region could also lead to increase in woody biomasses as

372 well as wood production. Furthermore, alternative sources of energy such as wind and

373 solar power, and bioenergy through accelerating the development of plantations on

374 deforested lands should be sought. Financial incentives made available through REDD

375 agreements should be used wholly or partially for such alternatives.

377 Incentives or investment in plantations of hybrid species which, grow faster and are

378 environmentally adaptable on already deforested lands would lead to the increase of woody

379 biomass and pulpwood production for bioenergy and paper. Plantations could also

380 decrease the pressure on natural forests whose ecosystem services and functioning are vital

381 to sustainable development. Mean annual increment of some hybrid fast growing species

382 of Eucalyptus (such as E. grandis) reaches 53-60 $\mathrm{m}^{3} \mathrm{~h}^{-1} \mathrm{yr}^{-1}$ (about 39.7-45.0 tons of all

383 above-ground biomass) [48]. If this growth rate could be achieved, future supplies of

384 woody biomass and pulp are likely to come from forest plantations, while natural forests

385 are managed for full ecosystem services.

387 6. Conclusion

389 This study developed models to estimate forest land use changes, standing biomass, and

390 woody biomass (for bioenergy generation) in Southeast Asia between 1990 and 2020. It 
also discussed the incentives for reducing deforestation and implementing sustainable

392 forest management in the region. Our study methods could be applicable to any country or

393 region where selective logging is practiced.

394

395 The results show that Southeast Asian forests produce about 563.8 million tons $\mathrm{yr}^{-1}(11.3$

396 EJ) of woody biomass for the period spanning 1990 to 2020 . The annual production of 397 woody biomass decreases about $1.5 \%$ over the same period. Without appropriate measures 398 to reduce deforestation and bring forests under sustainable management, Southeast Asia is 399 likely to face a shortage of woody biomass. Furthermore, if the current deforestation and 400 forest degradation continue, wood production, woody biomass, climate regulation 401 (including carbon sequestration), watershed protection, and ecosystem functioning will be 402 adversely affected, which, in turn could put sustainable development in the region at risk 403 because a large part of population in this region depend on forests and their ecosystems for 404 daily survival. Countries in the region should take advantages of the international 405 agreements such as the Kyoto Protocol or post-Kyoto agreements, i.e. REDD, to reduce 406 deforestation and forest degradation. At the same time, alternative sources of woody 407 biomass, i.e. from forest rehabilitation and plantations, should be made available, because, 408 currently only $0.08 \%$ of the 2.4 million ha deforested land is converted to forest 409 plantations, and the majority of these lands are still available for plantation. 
411 Our results also suggest that using wood biomass to replace the use of fossil fuels for 412 energy generation could prevent carbon emissions of about $169.0-281.7 \mathrm{TgC}^{-1}{ }^{-1}$ between $413 \quad 1990$ and 2020.

414

\section{Acknowledgement}

416 This work is funded through the Harvard Forest's Charles Bullard Fellowship in Forest

417 Research for Advanced Research and Study at Harvard University and a Grant-in-Aid for 418 Scientific Research (No. 18402003) from the Ministry of Education, Culture, Sports, 419 Science, and technology of Japan. The authors gratefully thank Betsy Colburn and 420 Jonathan Thompson of Harvard Forest, Harvard University for commenting and English 421 editing. We also thank the editor and reviewers for their invaluable comments.

\section{References}

[1] UNFCCC. Press Release of the Conference of the Parties on its fourteenth session, held in Poznan from 1 to 12 December 2008. UNFCCC 2008

[2] Gullison FR, Frumhoff CP, Canadell GJ, Field CB, Nepstad DC, Hayhoe K, Avissar R, Curran LM, Friedlingstein P, Jones CD, Nobre C. Tropical forests and climate policy. Science 2007; 136: 985-986.

[3] Houghton RA. Revised estimates of the annual net flux of carbon to the atmosphere from changes in land use and land management 1850-2000. Tellus 55B 2003; 2: 378390.

[4] Gaye A. Access to energy and human development. Fighting climate change: Human solidarity in a divided world. Human Development Report 2007/2008. UNDP: New York; 2007. 
[5] Koopmans A. Biomass energy demand and supply for South and South-East Asia—assessing the resource base. Biomass and Bioenergy 2005; 28: 133-150

[6] Canadell JG, Raupach MR. Managing forests for climate change mitigation. Science 2008; 320: 1456-1457.

[7] Smeets MW, Faaij APC. Bioenergy potentials from forestry in 2050. An assessment of the drivers that determine the potentials. Climatic Change 2007; 81: 353-390.

[8] Kinoshita T, Inoue K, Iwao K, Kagemoto H, Yamagata Y. A spatial evaluation of forest biomass usage using GIS. Appl Energy 2009; 86(1): 1-8.

[9] Sathre R, Gustavsson L. Using wood products to mitigate climate change: External costs and structural change. Appl Energy 2009; 86(2) 251-257.

[10] Filho PA, Badr O. Biomass resources for energy in North-Eastern Brazil. Appl Energy 2004; 77: 51-67.

[11] Sist P, Saridan A. Stand structure and floristic composition of a primary lowland dipterocarp forest in East Kalimantan. Journal of Tropical Forest Sci. 1999; 11(4): 704-722.

[12] Sist P, Sheil D, Kartawinata K, Priyadi H. Reduced-impact logging in Indonesian Borneo: some results confirming the need for new silvicultural prescriptions. For Ecol Manage 2003; 179: 415-427.

[13] FAO. Financial and economic assessment of timber harvesting operations in Sarawak, Malaysia. Forest Harvesting Case - Studies 17. FAO, Rome; 2001.

[14] FAO. Regional study on wood energy today and tomorrow in Asia. Field Document No.50. Bangkok: FAO; 1997.

[15] FAO. Global forest resources assessment 2005. Progress towards sustainable forest management. FAO Forestry Paper 147, Rome; 2005.

[16] Kim Phat N, Knorr W, Kim S. Appropriate measures for conservation of terrestrial carbon stocks - analysis of trends of forest management in Southeast Asia. For Ecol Manage 2004; 191: 283-299.

[17] FAO. Global forest resource assessments 2000 (main report). FAO forestry paper 140, Rome; 2001. 
[18] Iskandar H, Snook LK, Toma T, MacDicken KG, Kanninen M. A comparison of damage due to logging under different forms of resource access in East Kalimantan, Indonesia. For Ecol Manage 2006; 237: 83-93.

[19] Sist P, Nolan T, Bertault JG, Dykstra DP. Harvesting intensity versus sustainability in Indonesia. For Ecol Manage 1998; 108: 251-260.

[20] Hall DO. Biomass energy in industrialised countries. A view of the future. For Ecol Manag 1997; 91:17-45.

[21] Loehnertz PS, Cooz VI, Guerrero J. Sawing hardwoods in five tropical countries. Forest Products Journal 1996; 46: 51-56.

[22] Brown S. Estimating biomass and biomass change of tropical forests: a Primer. FAO Forestry Paper 134, Rome; 1997.

[23] Nascimentoa EMH, Laurance FW. Total aboveground biomass in central Amazonian rainforests: a landscape-scale study. For Ecol Manage 2002; 168: 311-321

[24] Holmes TP, Blate GM, Zweede JC, Pereira R, Barreto P, Boltz F, Bauch R. Financial and ecological indicators of reduced impact logging performance in the eastern Amazon. For Ecol Manage 2002; 163: 93-110.

[25] Sist P, Saridan A. Description of the primary lowland forest of Berau. In: Bertault JG amd Kadir K, editors. Silvicultural research in a lowland mixed dipterocarp forest of East Kalimantan. The contribution of STREK project. CIRAD-FORDA-P.T. INHUTANII; 1998, p. 51-94.

[26] Brown C. The global outlook for future wood supply from forest plantations. FAO Working Paper, GFPOS/WP/03, 156 pp.; 2000.

[27] Miranda I, Almeida MH, Pereira H (2007) Influence of provenance, subspecies, and site on wood density in Eucalyptus globulus Labill. Wood and Fiber Sci 2007; 33: 915.

[28] Arroja L, Dias AC, Capela I (2006) The role of Eucalyptus globulus forest and products in carbon sequestration. Climatic Change 2006; 74: 123-140.

[29] Varmola M, Del Lungo A. Planted forests database: structure and contents. FAO Planted Forests and Trees Working Papers FP/25. FAO, Rome; 2003. 
[30] Energy Information Administration (2006). International Energy Annual 2006. Online data accessed on 17 March 2009.

http://www.eia.doe.gov/emeu/international/energyconsumption.html

[31] Blasing TJ, Broniak C, Marland G. State-by-state carbon dioxide emissions from fossil-fuel use in the United States 1960-2000. Mitigation and Adaptation Strategies for Global Change 2005; 10: 659-674

[32] FAO. Selected indicators of food and agriculture development in Asia-Pacific region 1992-2002. RAP PUBLICATION : 2003/10, Bangkok: FAO; 2003.

[33] Yamamoto H, Yamaji K, Fujino J. Evaluation of bioenergy resources with a global land use and energy model formulated with SD technique. Appl Energy 1999; 63: 101-113.

[34] FAO. Asia-Pacific forestry towards 2010. Report of the Asia-Pacific forestry outlook study. Asia-Pacific Forestry Commission, Rome: FAO; 1998a.

[35] FAO. Global fibre supply model. Rome: FAO; 1998b.

[36] FAO. Global forest products consumption, production, trade and prices: global forest products model projections to 2010. Rome: FAO; 1998c.

[37] Kato T. Timber trafficking - Illegal logging in Indonesia, Southeast Asia and international consumption of illegally sourced timber. Kyoto Review of Southeast Asia 2002. Online Publication http://kyotoreview.cseas.kyotou.ac.jp/issue/issue $1 /$ article $151 \_$p.html

[38] Nawir AA, Murniati, Rumboko L (eds). Forest rehabilitation in Indonesia: Where to after three decades. Bogor: CIFOR; 2006

[39] Pulhin JM, Chokkalingam U, Peras RJJJ, Acosta RT, Carandang AP, Natividad MQ, Lasco RD, Razal RA. Chapter 2: historical overview. In: Chokkalingam U., Carandang AP, Pulhin JM, Lasco RD, Peras RJJ, Toma T (eds.), One century of forest rehabilitation in the Philippines: Approaches, outcomes and lessons. Bogor: CIFOR; 2006, pp. 6-41. 
[40] de Jong W, Sam DD, Hung TV. Forest rehabilitation in Vietnam: Histories, realities and future. Bogor: CIFOR; 2006.

[41] Meyfroidt P, Lambin EF. Forest transition in Vietnam and its environmental impacts. Glob Change Biol 2008; 14: 1-8.

[42] UNFCCC. Report of the Conference of the Parties on its thirteenth session, held in Bali from 3 to 15 December 2007. FCCC/CP/2007/6/Add, UNFCCC; 2008.

[43] International Institute for Sustainable Development. Summery of the fourteenth conference of the parties to the UNFCCC and fourteenth meeting of the Kyoto Protocol: 1-12 December 2008. Earth Negotiations Bulletin 2008; 12(395).

[44] Kindermann G, Obersteiner M, Sohngen B, Sathaye J, Andrasko K, Rametsteiner E, Schlamadinger B, Wunder S, Beach R. Global cost estimates of reducing carbon emissions through avoided deforestation. Proc Natl Acad Sci USA 2008; 105: 1030210307.

[45] Jha S, Bawa KS. Population Growth, Human Development, and Deforestation in Biodiversity Hotspots. Conservation Biology 2006; 20: 906-912.

[46] Morton DC, DeFries RS, Shimabukuro YE, Anderson LO, Arai E, del Bon EspiritoSanto F, Freitas R, Morisette J. Cropland expansion changes deforestation dynamics in the southern Brazilian Amazon. Proc Natl Acad Sci USA 2006; 103: 14637-14641.

[47] Putz FE, Zuidema PA, Pinard MA, Boot RG, Sayer JA, Sheil D, Sist P; Elias, Vanclay JK. Improved tropical forest management for carbon retention. PLoS Biol 2008; 6(7): e166 doi:10.1371/journal.pbio.0060166

[48] Smith NJH, Serrao EAS, Alvim PT, Falesi IC. Amazonia: Resiliency and Dynamism of the Land and Its People. Tokyo: United Nations University; 1995 


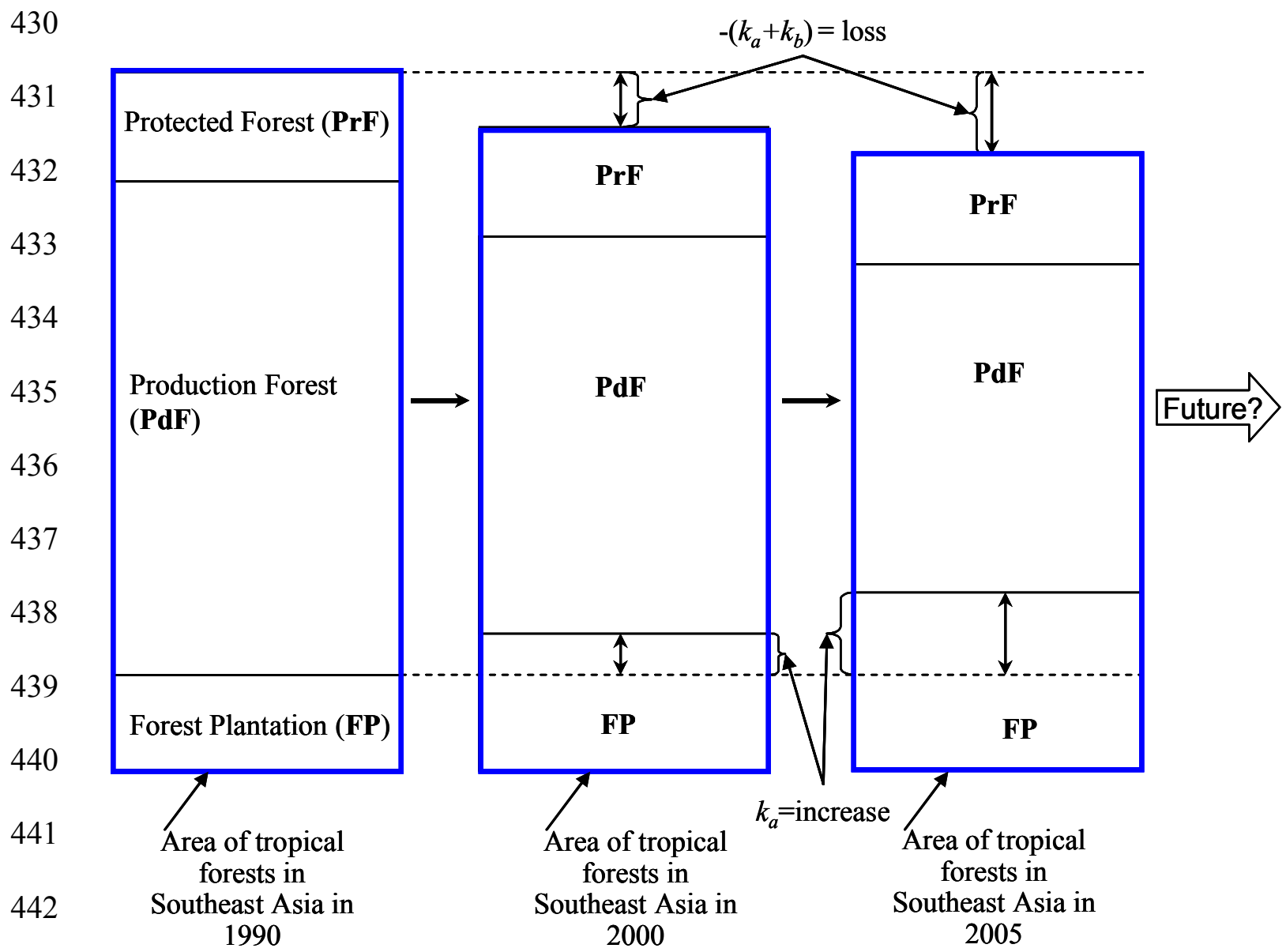

Fig. 1. Illustration of forest land use change model

444 Note: it is assumed that new plantations are established on deforested land only (i.e.

445 deforested PdF).

446

447

448

449

450 
452

453

454

455

456

457

458

459

460

461

462

463

464

465

466

467

468

469

470

Note
Natural Forests

Forest Plantations

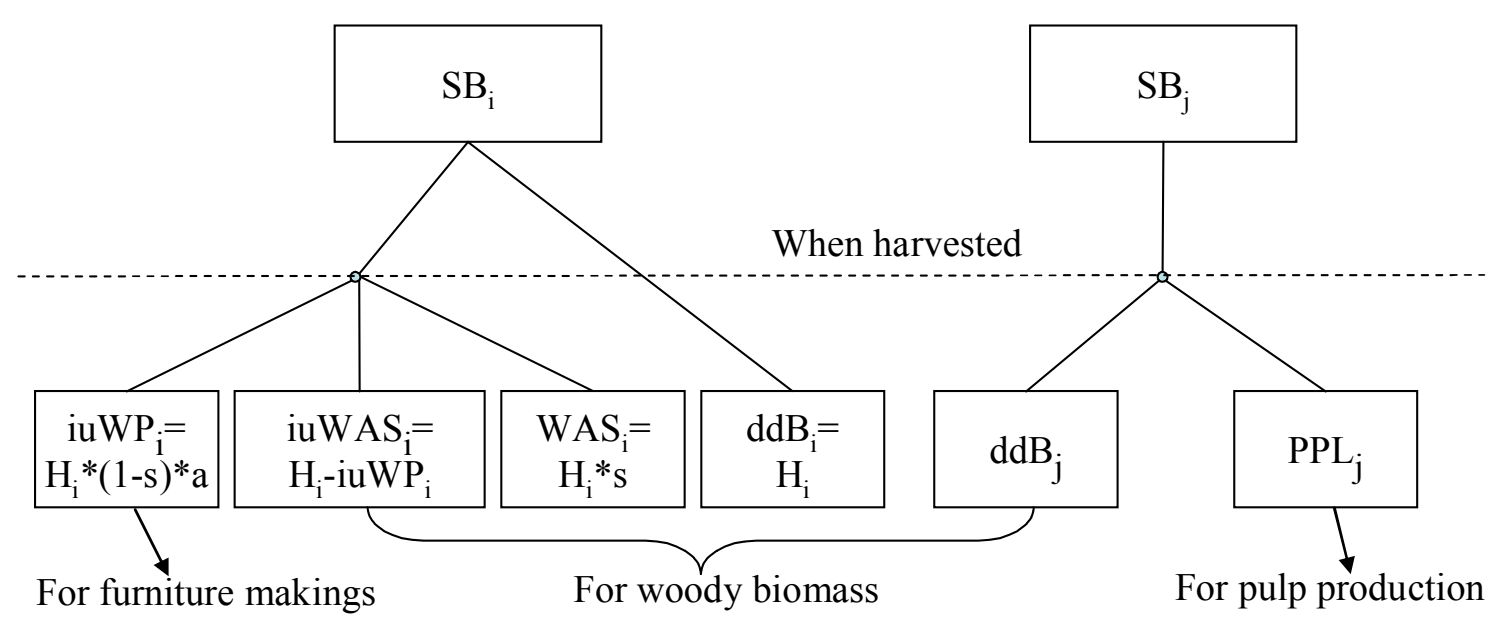

Fig. 2. Conceptual diagram for biomass allocation

$S B_{i}$ is standing biomass in natural forest $i, i u W P_{i}$ is in-use wood product; $i u W A S_{i}$ is in-use wasted wood, $W A S_{i}$ is wasted wood due to felling, skidding, trimming and/or transporting; $d d B_{i}$ is dead woody biomass caused by logging

$S B_{j}$ is standing biomass in forest plantation $j, d d B_{j}$ dead woody biomass in branches and top logs, $P P J_{j}$ is biomass in stem for pulp production $\left(\mathrm{PPJ}_{\mathrm{j}}=\mathrm{SB}_{\mathrm{j}} / \mathrm{BEF}_{\mathrm{j}}\right.$, where $\mathrm{BEF}$ is biomass expansion factor. $B E F_{j}$ values are presented in Table 4). 


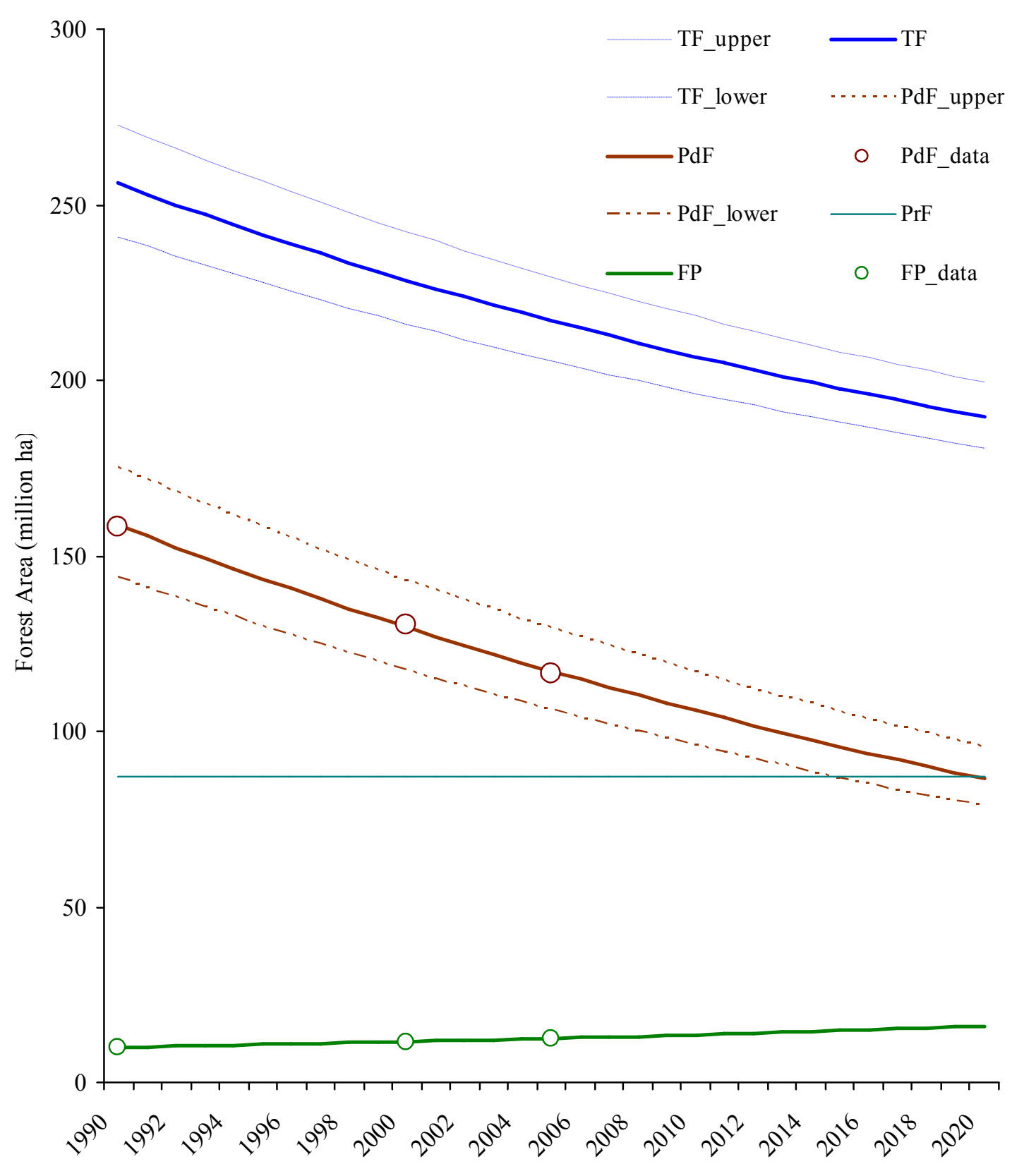

471

Fig. 3. Changes in area of forests in Southeast Asia (1990-2020)

473 Note: Confidence intervals for FP are not included because they are very small 474 


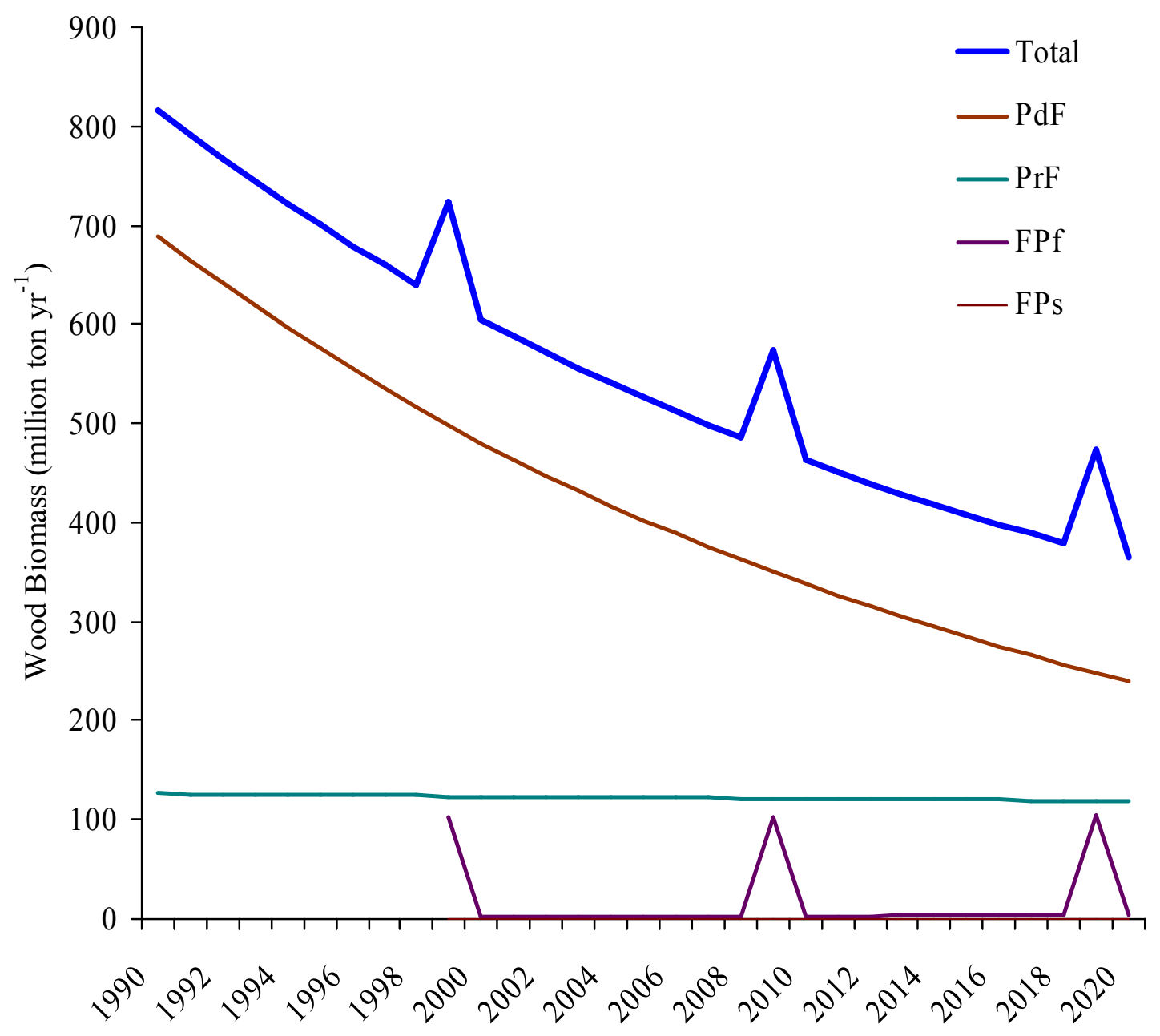

475

Fig. 4. Annual wood bioenergy production in Southeast Asia

$478 \quad$ Note

479 Fast growing plantation established in 1990 become harvestable in 1999. Its annual woody

480 biomass production is strongly affected by cutting rotation. Slow-growing plantation will

481 become harvestable in 2029 , and therefore more woody biomass production is expected 482 thereafter. 


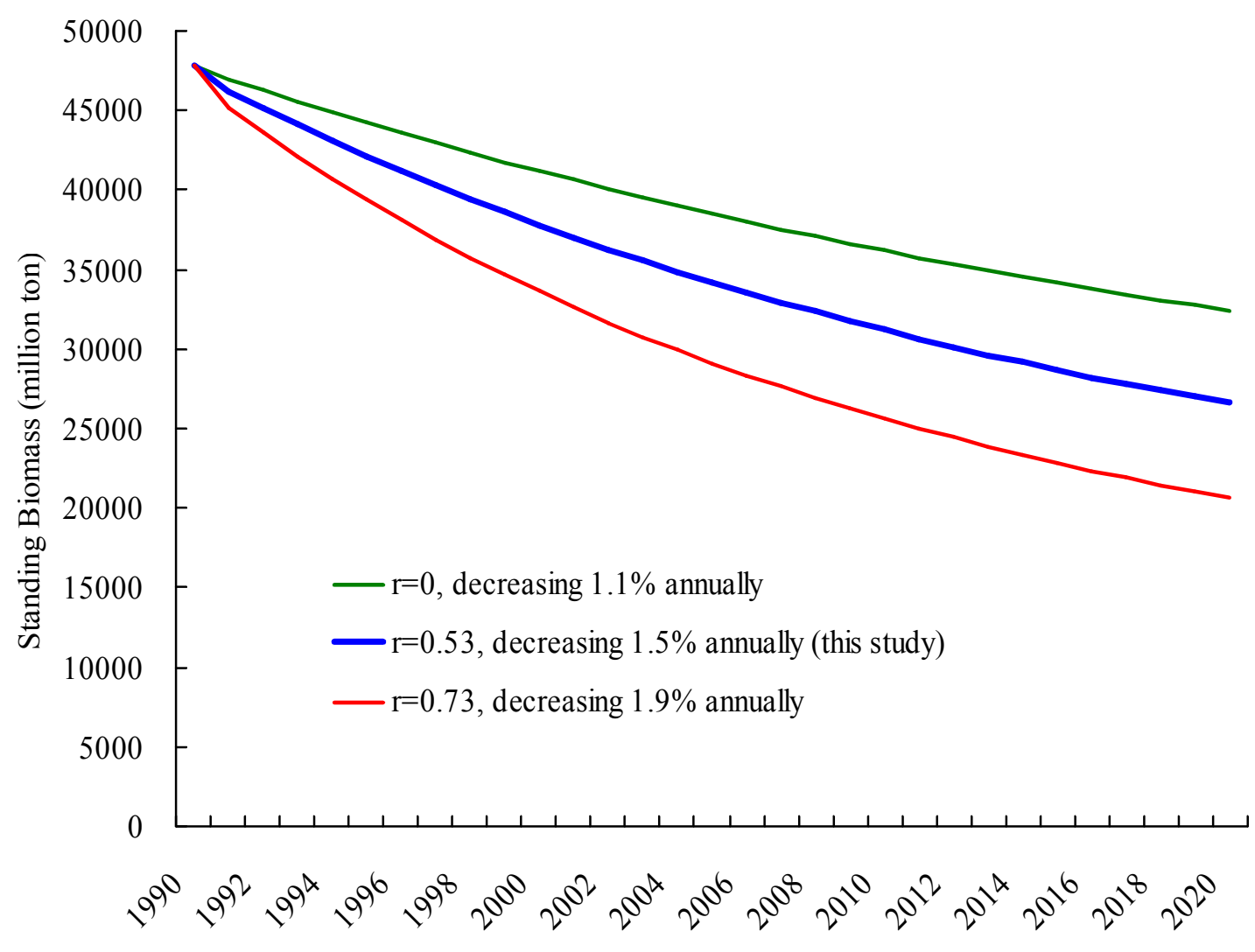




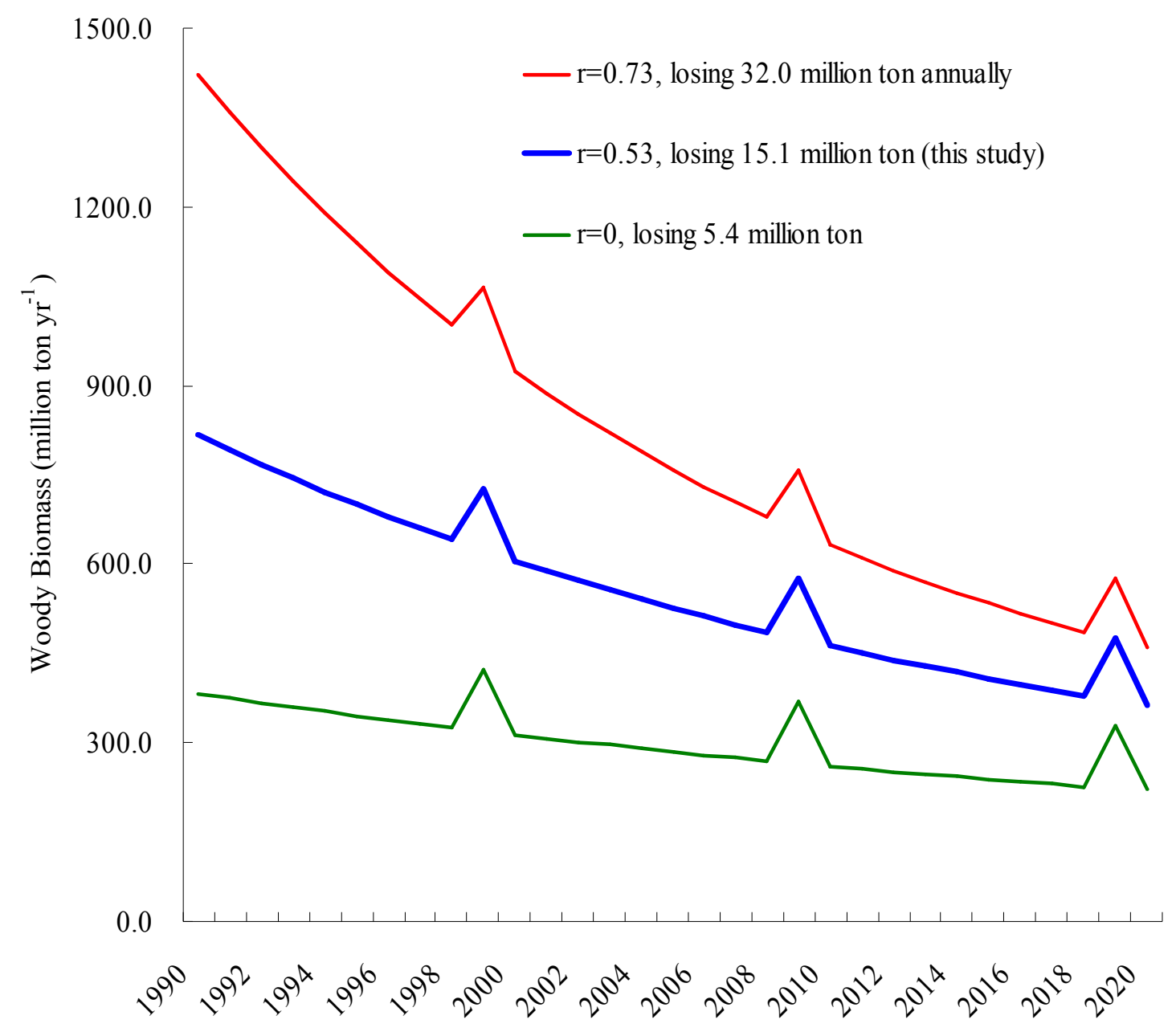

496 Fig. 6 Woody biomass production from all forests under different rates of illegal logging

497

498 Note

499 Illegal logging leads to more production of woody biomass in the beginning, but it starts

500 to decline sharply. Additionally, deforestation is also responsible for the gradual loss of

501 woody biomass as seen in the figure above (green line) when all illegal logging is halted. 


\section{Tables and Captions}

504

505 Table 1 Changes in area of forests in Southeast Asia 1990-2005

\begin{tabular}{lrrrrrrr}
\hline & \multicolumn{3}{c}{$1990($ '000 ha) } & \multicolumn{3}{c}{2005 ('000 ha) } \\
Country & \multicolumn{1}{c}{ NF } & \multicolumn{1}{c}{ FP } & \multicolumn{1}{c}{ Total } & \multicolumn{1}{c}{ Total } & \multicolumn{1}{c}{ NF } & \multicolumn{1}{c}{ FP } & Total \\
\hline Brunei Darussalam & 313.0 & 0.0 & 313.0 & 288.0 & 278.0 & 0.0 & 278.0 \\
Cambodia & 12946.0 & 67.0 & 13013.0 & 11613.0 & 10447.0 & 59.0 & 10506.0 \\
Indonesia & 116567.0 & 2209.0 & 118776.0 & 100854.0 & 88495.0 & 3399.0 & 91894.0 \\
Laos & 17314.0 & 4.0 & 17318.0 & 16631.0 & 16142.0 & 224.0 & 16366.0 \\
& & & & & & & \\
Malaysia & 22376.0 & 1956.0 & 24332.0 & 23250.0 & 20890.0 & 1573.0 & 22463.0 \\
Myanmar & 39219.0 & 394.0 & 39613.0 & 35250.0 & 32222.0 & 849.0 & 33071.0 \\
Philippines & 10574.0 & 1780.0 & 12354.0 & 8801.0 & 7162.0 & 620.0 & 7782.0 \\
Singapore & 2.0 & 0.0 & 2.0 & 2.0 & 2.0 & 0.0 & 2.0 \\
Thailand & 15965.0 & 2640.0 & 18605.0 & 17891.0 & 14520.0 & 3099.0 & 17619.0 \\
Timor-Leste & 966.0 & 29.0 & 995.0 & 897.0 & 798.0 & 43.0 & 841.0 \\
Viet Nam & 9363.0 & 967.0 & 10330.0 & 13775.0 & 12931.0 & 2695.0 & 15626.0 \\
Total & 245605.0 & 10046.0 & 255651.0 & 229252.0 & 203887.0 & 12561.0 & 216448.0 \\
Total (million ha) & 245.6 & 10.0 & 255.6 & 229.2 & 203.9 & 12.6 & 216.4 \\
\hline
\end{tabular}

506 Source: FAO [15]

507

508

509

510

511

512

513

514

515 
517 Table 2 Data used to derive ${ }^{* 1}$ land use model's initial values and parameters

\begin{tabular}{lcrrrrrr} 
Year & \multicolumn{3}{c}{ NF (million ha) } & \multicolumn{3}{c}{ FP (million ha) } & Tropical Forests \\
& PdF & PrF & Subtotal & FPf & FPs & Subtotal & (million ha) \\
\hline 1990 & 158.4 & - & 245.6 & - & - & 10.0 & 255.7 \\
2000 & 130.5 & - & 217.7 & - & - & 11.6 & 229.3 \\
2005 & 116.7 & 87.2 & 203.9 & & & 12.6 & 216.4 \\
Initial & 158.7 & 87.2 & & & & 10.1 & \\
value & & & & & & & \\
Parameters & $-\left(k_{a}+k_{b}\right)=$ & & & & & $k_{a}=0.0009$ & \\
& -0.0202 & & & & & & \\
\hline
\end{tabular}

$518 \quad$ Note

$519 *{ }^{1}$ Least square method was used to derive initial values and parameters

520 NF: Natural forests

521 PdF: Natural production forest

522 PrF: Natural protected forest

523 FP: Forest plantations

524 FPf: Fast growing forest plantation

525 FPs: Slow growing forest plantation

526

527

528

529

530

531

532 
533 Table 3 Initial values and parameters for modeling biomass in natural forests

\begin{tabular}{|c|c|c|c|c|}
\hline & $\mathrm{PdF}$ & $\operatorname{PrF}$ & Unit & Remarks and Sources \\
\hline Stem Volume & 200 & 200 & $\mathrm{~m}^{3} \mathrm{ha}^{-1}$ & Taken from Kim Phat et al. [16] \\
\hline $\begin{array}{l}\mathrm{SB}(0)^{* 1} \\
(\text { stand biomass at } \mathrm{t}=0)\end{array}$ & 194.6 & 194.6 & ton $\mathrm{ha}^{-1}$ & $\begin{array}{l}\text { dry wood including branches, } \\
\text { but without leaves }\end{array}$ \\
\hline $\begin{array}{l}\mathrm{MAI}^{* 2} \\
\text { (mean annual increment) }\end{array}$ & 1.0 & 1.0 & $\begin{array}{l}\text { ton } \mathrm{ha}^{-1} \\
\mathrm{yr}^{-1}\end{array}$ & $\begin{array}{l}\text { dry wood including branches } \\
\text { (no leaves, } 1.9 \% \text { of all; } \\
\text { converted from [16] }\end{array}$ \\
\hline $\begin{array}{l}f_{W} \\
\text { (fraction of harvested stand } \\
\text { biomass) }\end{array}$ & 0.3 & 0.1 & $\%$ & $\begin{array}{l}30 \% \text { of stand biomass of mature } \\
\text { trees }([16] \text { for } \operatorname{PdF}, 10 \% \text { is } \\
\text { assumed for } \operatorname{PrF}\end{array}$ \\
\hline $\begin{array}{l}\mathrm{f}_{\mathrm{T}} \\
\text { (fraction of mature-tree } \\
\text { stand biomass) }\end{array}$ & 0.5 & 0.5 & $\%$ & $\begin{array}{l}50 \% \text { mature biomass take from } \\
{[\text { Kim Phat et al. } 16]}\end{array}$ \\
\hline $\begin{array}{l}\mathrm{CC} \\
\text { (cutting cycle) }\end{array}$ & 30 & 30 & yrs & [16] \\
\hline (rate of illegal logging) & 0.53 & 0.53 & $\%$ & {$[16]$} \\
\hline $\begin{array}{l}\mathrm{s}^{* 3} \\
\text { (fraction of wasted wood) }\end{array}$ & 0.3 & 0.3 & $\%$ & $\mathrm{See}^{* 3}$ \\
\hline $\begin{array}{l}\mathrm{a}^{*^{4}} \text { (see Fig. 1) } \\
\text { (processing efficiency) }\end{array}$ & 0.5 & 0.5 & $\%$ & {$[21]$} \\
\hline $\begin{array}{l}\text { WD } \\
\text { (wood density) }\end{array}$ & 0.57 & 0.57 & ton $\mathrm{m}^{-3}$ & {$[22]$} \\
\hline $\begin{array}{l}\text { BEF } \\
\text { (biomass expansion factor) }\end{array}$ & 1.74 & 1.74 & & {$[22]$} \\
\hline Leaves, $1 *^{5}$ & 0.019 & 0.019 & & {$[23]$} \\
\hline Energy Content & 20 & GJ per ove & en try ton & {$[20]$} \\
\hline
\end{tabular}

534

535

536

537

538

539

540

541

542

543

544

545

546

547

548

\section{Note}

$* 1=\mathrm{V} * \mathrm{WD} * \mathrm{BEF}^{*}(1-l)$, leaves are considered as litters that are left behind as nutrients

$*^{2}=1 * \mathrm{WD}^{*} \mathrm{BEF}^{*}(1-l)$, MAI in stem is $1 \mathrm{~m}^{3} \mathrm{ha}^{-1} \mathrm{yr}^{-1}$ (based on Kim Phat et al. [16])

$*^{3}$ : based on FAO [13], Homes et al. [24], and Sist and Sridan [25]

$*^{4}$ : Based on Loehnertz et al. [21]

$*^{5}:$ based on Nascimentoa and Laurance [23] 
Table 4 Mean annual increments and cutting rotations for forest plantations

\begin{tabular}{|c|c|c|c|c|c|c|}
\hline \multirow[t]{3}{*}{ Species } & \multicolumn{4}{|c|}{ MAI Range $\left(\mathrm{ha}^{-1} \mathrm{yr}^{-1}\right)$} & \multirow{3}{*}{$\begin{array}{l}\text { Rotation } \\
(\mathrm{yrs})^{*}\end{array}$} & \multirow[t]{3}{*}{ Countries } \\
\hline & \multicolumn{2}{|c|}{$X\left(\mathrm{~m}^{3}\right)$} & \multicolumn{2}{|c|}{$\mathrm{Y}($ ton$)$} & & \\
\hline & Min & Max & Min & Max & & \\
\hline $\begin{array}{l}\text { Acacia } \\
\text { auriculiformis }\end{array}$ & 6.5 & 10.0 & 4.8 & 7.4 & 15 & $\begin{array}{l}\text { Myanmar, Philippines, Thailand } \\
\text { and Vietnam }\end{array}$ \\
\hline \multirow[t]{2}{*}{ Acacia mangium } & 12.0 & 19.0 & 8.8 & 14.0 & 8 & $\begin{array}{l}\text { Indonesia, Malaysia and Papua } \\
\text { New Guinea }\end{array}$ \\
\hline & 8.0 & 12.5 & 5.9 & 9.2 & & Laos, Philippines, and Vietnam \\
\hline \multirow[t]{2}{*}{ Eucalyptus species } & 8.0 & 12.5 & 5.9 & 9.2 & $5-15$ & Philippines,Thailand \\
\hline & 6.5 & 10.0 & 4.8 & 7.4 & & Malaysia \\
\hline Mean & 8.2 & 12.8 & 6.0 & 9.4 & & \\
\hline \multicolumn{3}{|c|}{ For this study (fast growing species) } & 7.7 & & 10 & \\
\hline \multirow[t]{2}{*}{ Casuarina species } & 5.0 & 7.5 & 4.9 & 7.3 & $15-35$ & India and Vietnam \\
\hline & 1.5 & 2.5 & 1.5 & 2.4 & & $\begin{array}{l}\text { Angola, Benin, Cuba, Kenya, } \\
\text { Madagascar, Mauritius, } \\
\text { Mozambique, Senegal, Somalia } \\
\text { and Thailand }\end{array}$ \\
\hline Dalbergia sissoo & 3.0 & 5.0 & 2.9 & 4.9 & 24 & $\begin{array}{l}\text { Bangladesh, Bhutan, Burkina } \\
\text { Faso, India, Nepal, Nigeria and } \\
\text { Pakistan }\end{array}$ \\
\hline $\begin{array}{l}\text { Swietenia } \\
\text { macrophylla }\end{array}$ & 5.0 & 7.5 & 4.9 & 7.3 & 32 & Indonesia and Philippines \\
\hline Terminalia species & 5.0 & 7.5 & 4.9 & 7.3 & & Bhutan, India and Jamaica \\
\hline \multirow[t]{2}{*}{ Tectona grandis } & 8.0 & 18.0 & 7.8 & 17.5 & 44 & $\begin{array}{l}\text { Colombia, Costa Rica, Jamaica, } \\
\text { Nicaragua, Panama and Trinidad } \\
\text { and Tobago }\end{array}$ \\
\hline & 4.0 & 6.0 & 3.9 & 5.8 & & $\begin{array}{l}\text { Indonesia, Laos, Malaysia, } \\
\text { Myanmar, Philippines, Thailand, } \\
\text { and Vietnam }\end{array}$ \\
\hline Mean & 4.5 & 7.7 & 4.4 & 7.5 & & \\
\hline \multicolumn{3}{|c|}{ For this study (slow growing species) } & 5.9 & & 40 & \\
\hline
\end{tabular}

Source: Brown [26]

Note:

$553 \mathrm{Y}=\mathrm{X} \times \mathrm{WD} \times \mathrm{BEF} \times(1-0.019)$ where $\mathrm{WD}$ is wood density, $\mathrm{WD}=0.5$ based on Miranda et al.

554 [27] and Arroja et al. [28] for fast growing species and $\mathrm{WD}=0.57$ [22] for slow growing

555 species; and $\mathrm{BEF}$ is biomass expansion factor, $\mathrm{BEF}=1.50$ [26]. (2006) and 1.74 [22] for

556 fast growing and slow growing species, respectively, 0.019 is $1.9 \%$ in leaves [23]

*: Rotation length was taken as an average of rotation length of major species reported in 
Table 5 Parameters for modeling biomass in forest plantations

\begin{tabular}{|c|c|c|c|c|}
\hline & FPf & FPs & Unit & Remarks and Source \\
\hline $\mathrm{B}_{\mathrm{MAX}}$ & 200 & 300 & ton $\mathrm{ha}^{-1}$ & $\begin{array}{l}\text { Maximum standing biomass (all } \\
\text { aboveground but without leaves) }\end{array}$ \\
\hline $\mathrm{B}(0)$ & 7.7 & 5.9 & ton $\mathrm{ha}^{-1}$ & $\begin{array}{l}\text { All aboveground but without } \\
\text { leaves }\end{array}$ \\
\hline$\alpha$ & 0.2765 & 0.1337 & & \\
\hline MAI & 7.7 & 5.9 & ton $\mathrm{ha}^{-1} \mathrm{yr}^{-1}$ & {$[26]$} \\
\hline $\mathrm{CC}$ & 10 & 40 & yrs & {$[26]$} \\
\hline WD & 0.50 & 0.57 & & $\begin{array}{l}\text { [27] for fast, [22] for slow } \\
\text { growing plantation }\end{array}$ \\
\hline $\mathrm{BEF}$ & 1.50 & 1.74 & & $\begin{array}{l}\text { [28] for fast, [22] for slow } \\
\text { growing plantation }\end{array}$ \\
\hline Litters & 0.019 & 0.019 & & {$[23]$} \\
\hline $\begin{array}{l}\text { Energy } \\
\text { Content }\end{array}$ & 20 & GJ per oven $t$ & ry ton & {$[20]$} \\
\hline
\end{tabular}


Table 6 Mean annual changes in area of natural forests and forest plantations (1990-2020)

\begin{tabular}{lrrrr}
\hline \multirow{2}{*}{ Forests } & \multicolumn{2}{c}{$1990-2005$} & \multicolumn{2}{c}{$1990-2020$} \\
& (million ha) & $(\%$ to 1990) & (million ha) & (\% to 1990) \\
\hline Natural Forests & -2.8 & -1.7 & -2.4 & -1.5 \\
PdF & -2.8 & -1.7 & -2.4 & -1.5 \\
PrF & 0 & 0 & 0 & 0 \\
Forest Plantations & 0.2 & 1.7 & 0.2 & 2.0 \\
PFf & 0.1 & 0.8 & 0.1 & 0.9 \\
PFs & 0.1 & 0.9 & 0.1 & 1.0 \\
Total & -2.6 & -1.0 & -2.2 & -0.9 \\
\hline
\end{tabular}

593

594

595

596

597

598

599

600

601

602

603

604

605

606

607

608

609

610

611

612

613

614

615

616 
617 Table 7 Total standing biomass in natural forests and forest plantations (1990-2020)

\begin{tabular}{lrrrrr}
\hline \multirow{2}{*}{ Forest Type } & \multirow{2}{*}{1990} & 2005 & 2020 & \multicolumn{2}{c}{ Annual Change } \\
& \multicolumn{3}{c}{ million tons } & \multicolumn{2}{c}{ million tons $\mathrm{yr}^{-1}$} \\
Natural Forests & 47858.7 & 34202.9 & 26597.4 & -910.4 & -708.7 \\
PdF & 30884.7 & 17765.9 & 10611.6 & -874.6 & -675.8 \\
PrF & 16974.1 & 16436.9 & 15985.8 & -35.8 & -32.9 \\
Forest Plantations & 67.8 & 367.4 & 1013.8 & 20.0 & 31.5 \\
PFf* & 36.4 & 150.2 & 92.5 & 7.6 & 1.9 \\
& & & & & \\
PFs $^{2}$ & 31.4 & 217.2 & 921.3 & 12.4 & 29.7 \\
Total & $\mathbf{4 7 9 2 6 . 6}$ & $\mathbf{3 4 5 7 0 . 3}$ & $\mathbf{2 7 6 1 1 . 2}$ & $\mathbf{- 8 9 0 . 4}$ & $\mathbf{- 6 7 7 . 2}$ \\
Total (EJ*3) & $\mathbf{9 5 8 . 5}$ & $\mathbf{6 9 1 . 4}$ & $\mathbf{5 5 2 . 2}$ & $\mathbf{- 1 7 . 8}$ & $\mathbf{- 1 3 . 5}$ \\
& & & & & \\
In terms of carbon stock changes & $\left(\mathrm{TgC} \mathrm{yr}^{-1}\right)^{* 4}$ & & \\
Natural Forests & 23929.4 & 17101.4 & 13298.7 & 455.2 & 354.4 \\
Forest Plantations & 33.9 & 183.7 & 506.9 & -10.0 & -15.8 \\
Total & $\mathbf{2 3 9 6 3 . 3}$ & $\mathbf{1 7 2 8 5 . 1}$ & $\mathbf{1 3 8 0 5 . 6}$ & $\mathbf{4 4 5 . 2}$ & $\mathbf{3 3 8 . 6}$ \\
\hline
\end{tabular}

618

619 Note:

$620 * 1$ : Standing biomass is strongly affected by cutting rotation

$621 *^{2}$ : Standing biomass will be harvested in 2029 , thereafter standing biomass will be 622 reduced.

$623 *^{3}$ : EJ is exajoule $\left(1 \mathrm{EJ}=10^{9} \mathrm{GJ}\right)$

$624 *^{4}$ : Multiplying by 0.5 carbon content in dry woody biomass. One Tetragram Carbon

$625(\mathrm{TgC})$ is one million tons of carbon

$626 *^{5}$ : Minus sign (-) refers to carbon sinks

627

628

629

630

631

632

633

634 
635 Table 8 Mean annual woody biomass and bioenergy production, end-use wood and pulp 636 production in Southeast Asia

\begin{tabular}{|c|c|c|c|c|c|c|c|c|}
\hline \multirow{3}{*}{ Forests } & \multicolumn{4}{|c|}{$1990-2005$} & \multicolumn{4}{|c|}{$1990-2020$} \\
\hline & \multicolumn{2}{|c|}{ million tons $\mathrm{yr}^{-1}$} & \multicolumn{2}{|c|}{ EJ $\mathrm{yr}^{-1}$} & \multicolumn{2}{|c|}{ million tons $\mathrm{yr}^{-1}$} & \multicolumn{2}{|c|}{$\mathrm{EJ} \mathrm{Jr}^{-1}$} \\
\hline & Mean & s.e. $*^{3}$ & Mean & s.e. & Mean & s.e. & Mean & s.e. \\
\hline \multicolumn{9}{|l|}{ Natural Forests } \\
\hline $\mathrm{BIE}$ & 657.8 & 23.0 & 13.2 & 0.5 & 547.2 & 24.6 & 10.9 & 0.5 \\
\hline BIF (million $\left.\mathrm{m}^{3}\right)^{* 1}$ & 110.6 & 3.9 & & & 92.0 & 4.1 & & \\
\hline \multicolumn{9}{|l|}{$\mathrm{PdF}$} \\
\hline $\mathrm{BIE}$ & 533.4 & 22.7 & 10.7 & 0.5 & 424.5 & 24.3 & 8.5 & 0.5 \\
\hline BIF (million $\left.\mathrm{m}^{3}\right)^{* 1}$ & 89.7 & 3.8 & & & 71.4 & 4.1 & & \\
\hline \multicolumn{9}{|l|}{$\operatorname{PrF}$} \\
\hline $\mathrm{BIE}$ & 124.4 & 0.3 & 2.5 & 0.0 & 122.6 & 0.4 & 2.5 & 0.0 \\
\hline $\mathrm{BIF}\left(\text { million } \mathrm{m}^{3}\right)^{* 1}$ & 20.9 & 0.1 & & & 20.6 & 0.1 & & \\
\hline \multicolumn{9}{|l|}{ Forest Plantations } \\
\hline $\mathrm{BIE}$ & 15.7 & 14.3 & 0.3 & 0.3 & 16.2 & 7.5 & 0.3 & 0.2 \\
\hline $\mathrm{BIP}\left(\text { million } \mathrm{m}^{3}\right)^{* 1}$ & 62.8 & 57.2 & & & 64.8 & 30.2 & & \\
\hline \multicolumn{9}{|l|}{ FPf } \\
\hline BIE & 15.7 & 14.3 & 0.3 & 0.3 & 16.2 & 7.5 & 0.3 & 0.2 \\
\hline $\mathrm{BIP}\left(\text { million } \mathrm{m}^{3}\right)^{* 1}$ & 62.8 & 57.2 & & & 64.8 & 30.2 & & \\
\hline \multicolumn{9}{|l|}{ FPs } \\
\hline $\mathrm{BIE}$ & 0 & & & & 0 & & & \\
\hline BIP $\left(\text { million } \mathrm{m}^{3}\right)^{* 1}$ & 0 & & & & 0 & & & \\
\hline \multicolumn{9}{|l|}{ Total } \\
\hline BIE (million ton) & 673.5 & & 13.5 & & 563.4 & & 11.3 & \\
\hline BIF (million $\mathrm{m}^{3}$ ) & 110.6 & & & & 92.0 & & & \\
\hline $\mathrm{BIP}\left(\right.$ million $\mathrm{m}^{3}$ ) & 62.8 & & & & 64.8 & & & \\
\hline \multicolumn{9}{|c|}{ 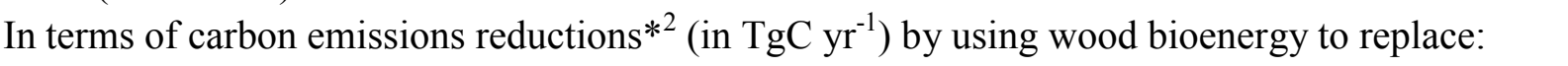 } \\
\hline Coal & & & 336.7 & & & & 281.7 & \\
\hline Petroleum products & & & 269.4 & & & & 225.3 & \\
\hline Natural gas & & & 202.0 & & & & 169.0 & \\
\hline
\end{tabular}

637 Note

$638 *^{1}$ : is converted by taking biomass dividing by wood density

$639 *^{2}$ : is derived by multiplying bioenergy $\left(1 \mathrm{EJ}=10^{9} \mathrm{GJ}\right)$ with carbon coefficients of $25 \mathrm{KgC}$

$640 \mathrm{GJ}^{-1}$ for coal, $20 \mathrm{KgC} \mathrm{GJ}^{-1}$ for petroleum products, and $15 \mathrm{KgC} \mathrm{GJ}^{-1}$ for natural gas [31]

641 and dividing by $10^{9}\left(1 \mathrm{TgC}=10^{9} \mathrm{KgC}\right)$

$642 *^{3}$ : s.e. is standard error 
643 BIE: woody biomass available for bioenergy

644 BIF: biomass available for furniture making

645 BIP: biomass available for pulp production (BIP)

646

647

648

649

650

651

652

653

654

655

656

657

658

659

660

661

662

663

664

665

666

667

668 
Table 9 Previous studies on wood bioenergy

\begin{tabular}{|c|c|c|c|c|}
\hline Authors & Methods & Major variables & Scale & Results \\
\hline This study & $\begin{array}{l}\text { Land use change model, } \\
\text { biomass stock change model, } \\
\text { biomass harvesting model }\end{array}$ & $\begin{array}{l}\text { Natural forests, forest } \\
\text { plantation, illegal } \\
\text { logging, forest } \\
\text { degradation }\end{array}$ & Regional & $\begin{array}{l}\text { Deforestation and forest degradation } \\
\text { reduce about } 18.1 \mathrm{EJ} \mathrm{yr}^{-1} \text { between } \\
1990-2020 \text {. Potential bioenergy is } \\
10.9 \mathrm{EJ} \mathrm{yr}^{-1} \text { between } 1990 \text { and } 2020 . \\
\text { Potential wood bioenergy (no illegal } \\
\text { logging) is } 7.0 \mathrm{EJ} \text { in } 1994 \text { and } 5.9 \mathrm{EJ} \\
\mathrm{yr}^{-1} \text { between } 1990 \text { and } 2020 .\end{array}$ \\
\hline $\begin{array}{l}\text { FAO-Regional } \\
\text { Wood Energy } \\
\text { Development } \\
\text { Program } \\
\text { Koopmans [5] } \\
\text { (2005) }\end{array}$ & $\begin{array}{l}\text { Extrapolation using data } 1990- \\
1995 . \text { Biomass growth is } \\
\text { assumed to increase } 1 \% \text { every } \\
\text { year. Biomass growth of } \\
\text { plantation was assumed at } 6-10 \\
\mathrm{~m}^{3} \mathrm{ha}^{-1} \mathrm{yr}^{-1} .80 \% \text { of non-wooded } \\
\text { lands also produce woodfuels }\end{array}$ & $\begin{array}{l}\text { Natural forests, forest } \\
\text { plantations, non- } \\
\text { wooded lands. No } \\
\text { illegal logging }\end{array}$ & Regional & $\begin{array}{l}\text { Potential wood bioenergy is } 6.7 \mathrm{EJ} \text { in } \\
1994 \text { from forested land in Southeast } \\
\text { Asia }\end{array}$ \\
\hline $\begin{array}{l}\text { Smeets \& Faaij } \\
(2007)[7]\end{array}$ & $\begin{array}{l}\text { Potential woody biomass in all } \\
\text { forests is obtained by } \\
\text { multiplying forest area and } \\
\text { gross annual increment (GAI) } \\
\text { under various scenarios. Data on } \\
\text { forest area and GAI were taken } \\
\text { from FAO [34], [35], [36] }\end{array}$ & $\begin{array}{l}\text { Natural forests, forest } \\
\text { plantations, and tree } \\
\text { outside forests. Only } \\
\text { GAI is harvested. }\end{array}$ & Global & $\begin{array}{l}\text { Deforestation reduces about } 13.0 \mathrm{EJ} \\
\mathrm{yr}^{-1} \text { between } 1998 \text { and } 2050\end{array}$ \\
\hline $\begin{array}{l}\text { Yamamoto et al. } \\
\text { (1999) [33] }\end{array}$ & $\begin{array}{l}\text { Global land-use and energy } \\
\text { model (GLUE) }\end{array}$ & $\begin{array}{l}\text { Natural forests, forest } \\
\text { plantations, arable } \\
\text { lands }\end{array}$ & Global & $\begin{array}{l}\text { Potential wood bioenergy is } 45.9- \\
85.2 \text { EJ in } 2100 \text { in all developing } \\
\text { countries worldwide }\end{array}$ \\
\hline
\end{tabular}

